\title{
Sistem Pendukung Keputusan Dalam Menentukan Kualitas Kopi Arabica Layak Ekspor Pada Pt. Indo Cafco Dengan Metode Multi Factor Evaluation Process
}

\author{
Darjat Saripurna \\ Program Studi Informasi, STMIK Triguna Dharma
}

\begin{tabular}{l}
\hline \hline Article Info \\
\hline Article history: \\
Received Mei $10^{\text {th }}, 2018$ \\
Revised June $13^{\text {th }}, 2018$ \\
Accepted Aug $04^{\text {th }}, 2018$
\end{tabular}

\section{Keyword:}

Sistem Pendukung Keputusan

Multi Factor Evaluation Process

(MFEP), Ekspor Kopi

\begin{abstract}
ABSTRAK
PT. Indo CafCo adalah perusahaan yang bergerak dibidang ekspor kopi. Dalam kegiatan operasionalnya PT. Indo CafCo dalam menentukan kualitas kopi yang layak ekspor belum memiliki sistem cerdas yang dapat mendukung keputusan terhadap hal tersebut.

Metode Multi Factor Evaluation Proces merupakan metode penjumlahan terbobot sederhana yang dapat menyelesaikan sebuah masalah berdasarkan skala prioritas, dalam penelitian ini diharapkan metode ini mampu memberikan solusi untuk penyeleksian kelayakan kualitas kopi dalam mendapatkan kualitas ekspor.

Hasil dari penelitian ini adalah terciptanya sebuah perangkat lunak yang mengadopsi metode MFEP sehingga membantu pihak manajemen PT. Indo CafCo dalam hal pemilihan kopi dengan kualitas layak ekspor yang pada akhirnya keputusan yang akan diambil secara tepat dan tanpa ada kekeliruan.
\end{abstract}

Copyright (C) 2018 STMIK Triguna Dharma. All rights reserved.

\author{
First Author \\ Nama : Darjat Saripurna, S.Kom, M.Kom \\ Program Studi : Sistem Informasi STMIK Triguna Dharma \\ Email : darjat_btw@yahoo.com
}

\section{PENDAHULUAN}

PT. Indo CafCo merupakan anak perusahaan dari ECOM Agroindustrial Corporation Limited, sebuah perusahaan terkemuka pemasok bahan komoditas mentah yang berbasis di Swiss, dengan operasi di lebih dari dua puluh negara dan kantor penjualan di Eropa, AS dan Asia. PT. Indo CafCo sendiri difokuskan pada pembelian kopi Arabica dari produsen yang berbasis di Sumatera Utara.

Dalam menentukan kualitas kopi layak ekspor, PT. Indo CafCo masih menggunakan cara manual yakni persepsi personal, mengakibatkan hasil akhir yang tidak memiliki keakuratan. Berdasarkan permasalahan yang ada sehingga dibutuhkan sebuah sistem pendukung keputusan guna membantu penentuan dalam menentukan kualitas kopi layak ekspor. Salah satu sistem pendukung keputusan yang dapat digunakan untuk mencari nilai prioritas tertinggi adalah dengan menggunakan Multi Factor Evaluation Process (MFEP).

Sistem Pendukung Keputusan (SPK) metode MFEP merupakan pengambilan keputusan secara subyektif dan intuitif dengan mempertimbangkan berbagai faktor atau kriteria yang mempunyai pengaruh penting terhadap alternatif pilihannya.

Pertimbangan-pertimbangan tersebut berupa pemberian bobot (weighting system) atas multi faktor yang terlibat dan dianggap penting. Metode MFEP menentukan bahwa alternatif dengan nilai tertinggi merupakan solusi terbaik berdasarkan kriteria atau pertimbangan yang telah dipilih.

Langkah dalam metode MFEP ini yang pertama adalah menentukan faktor-faktor yang dianggap penting, yang selanjutnya membandingkan faktor-faktor tersebut sehingga diperoleh urutan faktor berdasarkan kepentingannya dari yang terpenting, kedua terpenting dan seterusnya. Dalam masalah yang dibahas pada penelitian ini akan di rancang sebuah perangkat lunak berbasis desktop programming yang diharapkan menjadi solusi pemecahan masalah.

Desktop programming adalah program yang dilakukan dengan memanipulasi elemen-elemen visual. Perangkat lunak yang akan dirancang mengadopsi metode Multi Factor Evaluation Process. Pada konsep perancangan yang dilakukan dengan cara menentukan faktor-faktor yang menyebabkan masalah beserta bobotnya, lalu mencari nilai dan total nilai untuk setiap faktor yang mempengaruhi dalam pengambilan keputusan dari datadata yang akan diproses. Setelah itu di lakukan penjumlahan dari seluruh hasil evaluasi untuk memperoleh 
total hasil evalusi, lalu melakukan perangkingan untuk mendapatkan keputusan, dan pada fase akhir akan dilakukan sebuah perancangan sistem sehingga dapat menyelesaikan masalah sesuai dengan yang diharapkan.

\section{LANDASAN TEORITIS}

\subsection{Kualitas}

Menurut Triguno tentang kualitas, yang dimaksud dengan kualitas adalah "Suatu standar yang harus dicapai oleh seseorang atau kelompok atau lembaga atau organisasi mengenai kualitas sumber daya manusia, kualitas cara kerja, proses dan hasil kerja atau produk yang berupa barang dan jasa." (Triguno, 1997:76).

Pengertian kualitas tersebut menunjukan bahwa kualitas itu berkaitan erat dengan pencapaian standar yang diharapkan. Dari pengertian tersebut tampak bahwa, disamping kualitas itu menunjuk pada pengertian pemenuhan standar atau persyaratan tertentu, kualitas juga mempunyai pengertian sebagai upaya untuk melakukan perbaikan dan penyempurnaan secara terus menerus dalam pemenuhan kebutuhan pelanggan sehingga dapat memuaskan pelanggan

\subsection{Kopi}

Tanaman kopi adalah tanaman yang digolongkan ke dalam famili Rubiaceae dengan genus Coffea. Negara asal tanaman kopi adalah Abessinia yang tumbuh di dataran tinggi. Secara umum kopi hanya memiliki dua spesies yaitu Coffea arabica dan Coffea robusta (Saputra E., $2008: 33$ ).

Perbedaan di antara kedua varietas ini terutama terletak pada rasa dan tingkat kafeinnya. Biji arabika memiliki ciri-ciri ukuran biji yang lebih kecil dibandingkan biji kopi jenis robusta, lebih mahal di pasar dunia, serta memiliki rasa yang lebih lembut dan memiliki kandungan kafein $70 \%$ lebih rendah dibandingkan dengan biji robusta.

Tanaman kopi (Coffea spp.) merupakan komoditas ekspor unggulan yang dikembangkan di Indonesia karena mempunyai nilai ekonomis yang relatif tinggi di pasaran dunia. Asosiasi Eksportir Kopi Indonesia (AEKI) mencatat, produksi kopi di Indonesia 2016 sebesar 625.000 ton, sementara itu menurut data dari Kementerian Perdagangan RI , realisasi ekspor produk kopi hingga September 2016 mencapai 650,2 juta dolar AS menjadikan Indonesia berada di posisi keempat sebagai negara penghasil kopi terbesar di dunia

\subsection{Ekspor}

Ekspor adalah penjualan barang ke luar negeri dengan menggunakan sistem pembayaran, kualitas, kuantitas dan syarat penjualan lainnya yang telah disetujui oleh pihak eksportir dan importir. Penjualan barang oleh eksportir keluar negeri dikenai berbagai ketentuan dan pembatasan serta syarat-syarat khusus pada jenis komoditas tertentu termasuk cara penangan dan pengamanannya.

Dari sisi Undang-undang Nomor 10 Tahun 1995 tentang Kepabeanan sebagaimana telah diubah dengan Undang-undang Nomor 17 Tahun 2006, maka diperoleh pengertian ekspor yaitu kegiatan mengeluarkan barang dari daerah pabean sesuai peraturan dan perundang-undangan yang berlaku. Daerah pabean adalah wilayah RI yang meliputi wilayah darat, perairan, dan udara, serta tempat-tempat tertentu di zona ekonomi eksklusif dan landas kontinen yang didalamnya berlaku UU Nomor 17 Tahun 2006 tentang kepabeanan.

\subsection{Multi Factor Evaluation Process (MFEP)}

MFEP adalah metode kuantitatif yang menggunakan weighting system dalam pengambilan keputusan. Pengambilan keputusan dilakukan secara subyektif dan intuitif dengan menimbang berbagai faktor yang mempunyai pengaruh penting terhadap alternatif pilihan mereka. Untuk keputusan yang berpengaruh secara strategis, lebih dianjurkan menggunakan sebuah pendekatan kuantitatif seperti MFEP. Dalam MFEP pertamatama seluruh kriteria yang menjadi faktor penting dalam melakukan pertimbangan diberikan pembobotan (weighting) yang sesuai. Berikut merupakan langkah-langkah proses MFEP :

1. Menentukan faktor dan bobot faktor dimana nilai pembobotan harus sama dengan $1(\Sigma$ pembobotan $=1)$ yaitu faktor weight.

2. Memberi nilai untuk setiap faktor yang mempengaruhi dalam pengambilan keputusan dari data-data yang akan diproses, nilai yang dimasukkan dalam proses pengambilan keputusan merupakan nilai objektif.

3. Proses perhitungan weight evaluation yang merupakan proses perhitungan bobot antara factor weight dan factor evaluation dengan serta penjumlahan seluruh hasil weight evaluations untuk memperoleh total hasil evaluasi.

Penggunaan model Multifactor Evaluation Process dapat direalisasikan sebagai berikut :

1. Perhitungan nilai bobot evaluasi ditunjuk dalam Persamaan

Keterangan :

$$
W E=F W x E
$$

WE : Nilai bobot evaluasi

$F W \quad$ : Nilai bobot faktor 
E : Nilai evaluasi faktor

2. Perhitungan nilai total evaluasi ditunjuk dalam Persamaan

$$
\sum_{i=1}^{n} W E_{1}+W E_{2}+\cdots W E_{n}
$$

Keterangan :

$\sum_{i=1}^{n} W E_{i} \quad$ : Total nilai bobot evaluasi

$W E i \quad$ : Nilai bobot evaluasi ke-i

\section{ANALISIS DAN HASIL}

Syarat mutu umum kadar air biji kopi tidak lagi di bedakan berdasarkan jenis pengolahan (pengolahan basah dan kering) tetapi sama-sama maksimum $12.5 \%$. Persyaratan lain sama seperti sebelumnya yakni :

Tabel 1 Syarat Mutu Umum

\begin{tabular}{|l|l|l|}
\hline No & \multicolumn{1}{|c|}{ Kriteria } & \multicolumn{1}{|c|}{ Persyaratan } \\
\hline 1 & Serangga hidup & Tidak ada \\
\hline 2 & Biji berbau busuk dan atau berbau kapang & Tidak ada \\
\hline 3 & Kadar air & Maksimal 12,5\% \\
\hline 4 & Kadar kotoran & Maksimal 0,5\% \\
\hline
\end{tabular}

Sumber : Badan Standar Nasional Indonesia Adapun algoritma penyelesaian metode MFEP adalah sebagai berikut.

1. Menentukan faktor dan bobot faktor dimana total pembobotan harus sama dengan $1($ pembobotan $=1)$, yaitu Factor Weight

Tabel 2. Tabel Nilai Bobot untuk Faktor

\begin{tabular}{|c|l|c|c|}
\hline No & \multicolumn{1}{|c|}{ Faktor } & Bobot Faktor & $\begin{array}{c}\text { Importance } \\
\text { (Weight) }\end{array}$ \\
\hline 1 & Syarat Umum & $40 \%$ & 0.4 \\
\hline 2 & Syarat Khusus & $35 \%$ & 0.35 \\
\hline 3 & Nilai Cacat Kopi & $25 \%$ & 0.25 \\
\hline Jumlah & $1\left(\sum=1\right)$ \\
\hline
\end{tabular}

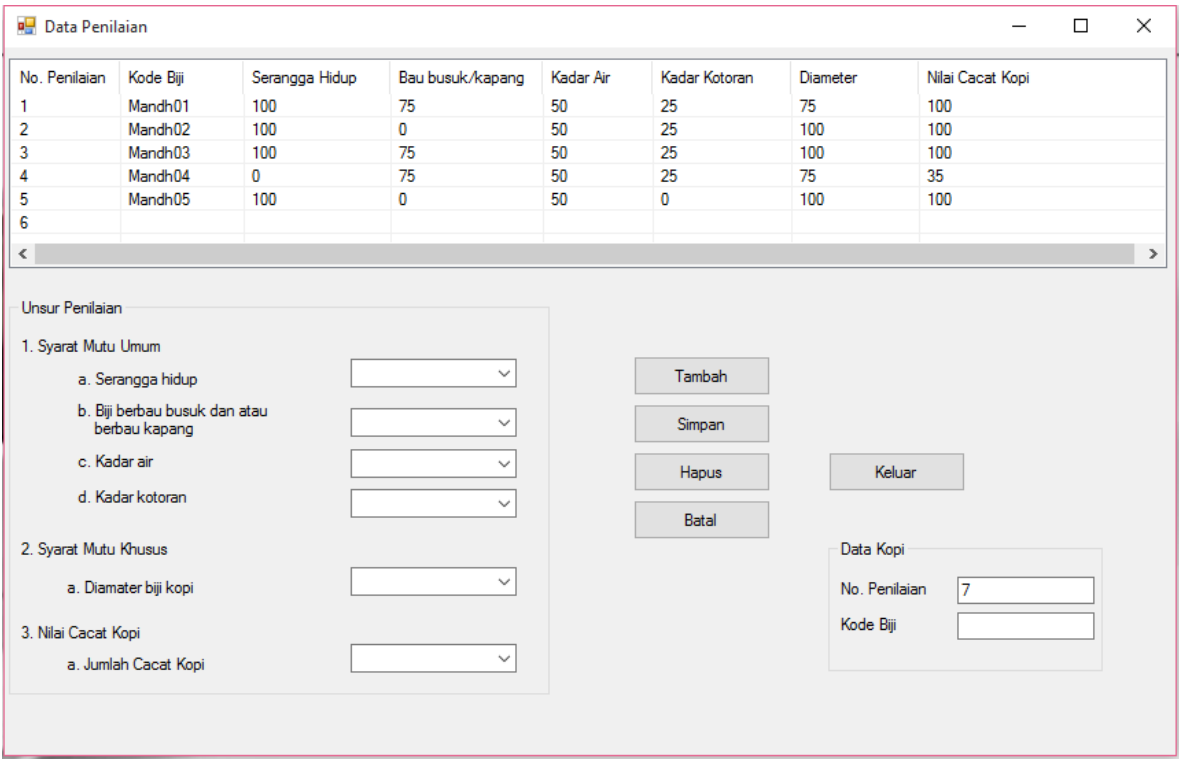

Gambar 1 Form Penilain 

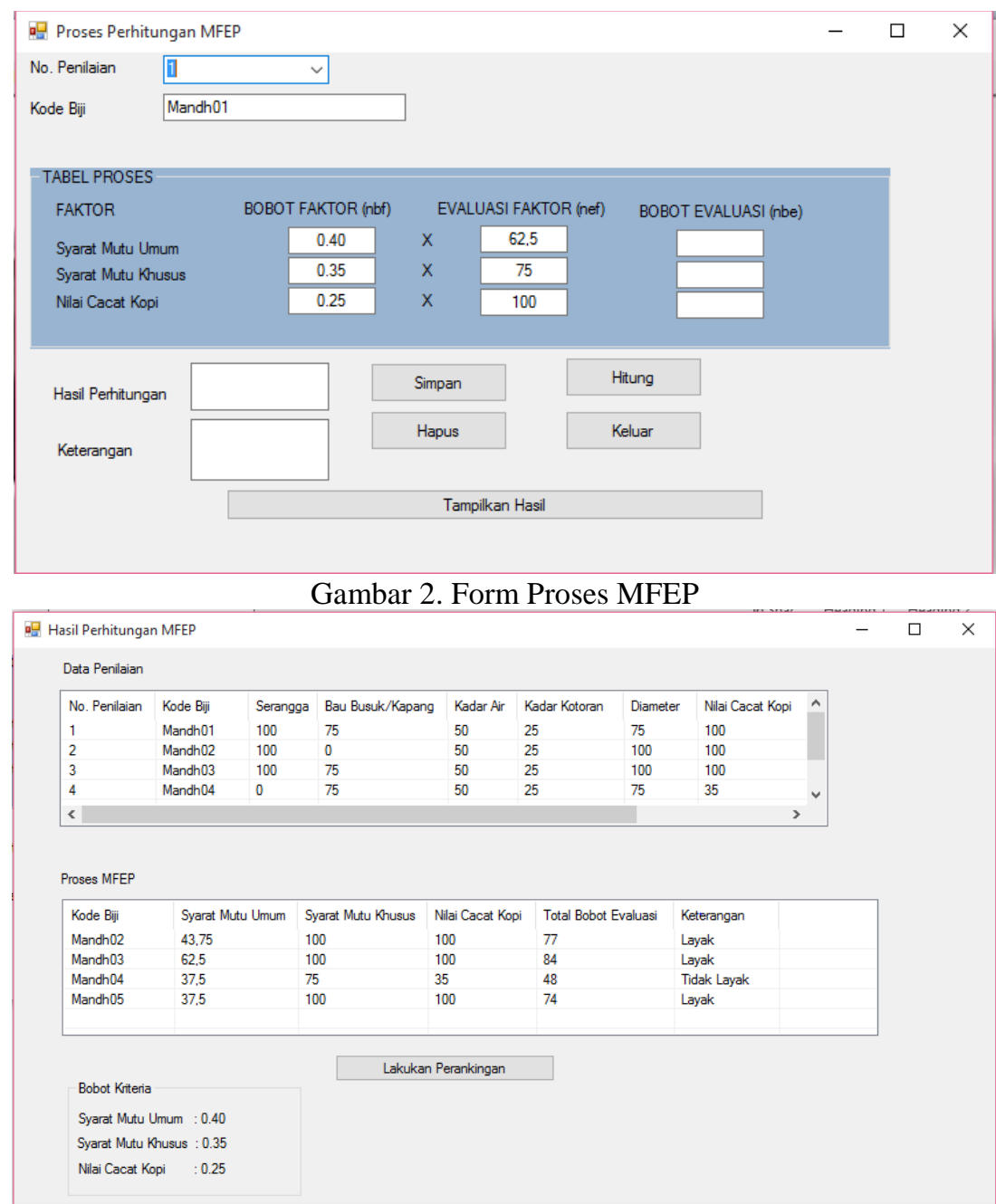

Gambar 3. Hasil Perhitungan MFEP

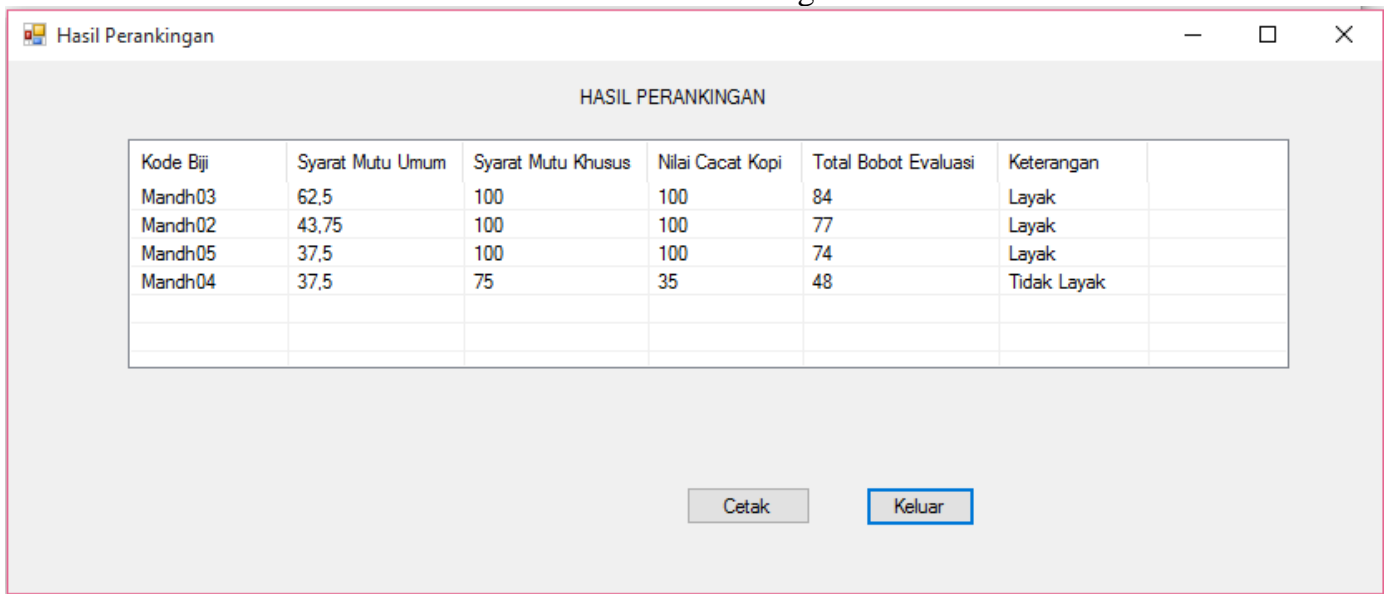

Gambar 4. Hasil Perankingan

\section{KESIMPULAN}

Dari hasil pembahasan pada bab sebelumnya dan penelitian yang telah dilakukan maka dapat diambil kesimpulan diantaranya sebagai berikut:

1. Sistem yang dapat membantu penentuan kualitas kopi layak ekspor dapat di rancang dan dibuat dengan mengadopsi Metode Multi Factor Evaluation Process.

2. Penerapan Metode MFEP dalam menentukan kualitas kopi arabika layak ekspor dilakukan melalui pemberian bobot pada setiap alternatif kopi lalu melakukan perhitungan atas bobot evaluasi dari setiap alternatif tersebut 
3. Pembangunan sistem pendukung keputusan menggunakan Multi Factor Evaluation Proces dapat dilakukan melalui pengkodean menggunakan bahasa pemrograman berbasis Dekstop Programming sehingga dapat menjadi solusi pemecahan masalah dalam hal penentuan kualitas kopi arabika layak ekspor

\section{DAFTAR PUSTAKA}

[1] Aziz. (2014) . Sistem Pendukung Keputusan Penyeleksian Calon Siswa Baru Di SMA Negeri 1 Kejayan Menggunakan Metode Multi-Factor Evaluation Process. Fakultas Teknik, Program Studi Teknik Informatika Universitas Yudharta Pasuruan Vol.6 No. 1

[2] Badan Standarisasi Nasional. (2001). SNI 19-8402-1991 Sistem Manajemen Mutu - Persyaratan. Jakarta : Badan Standarisasi Nasional.

[3] Badan Standarisasi Nasional. (2008). SNI 01-2907-2008 Biji Kopi. Jakarta : Badan Standarisasi Nasional.

[4] Bhara L.A.M. (2005). Pengaruh Pemberian Kopi Dosis Bertingkat Per Oral 30 Hari terhadap Gambaran Histology Hepar Tikus Wistar. Semarang : Universitas Diponegoro, Fakultas Kedokteran

[5] Kusrini. (2007). Konsep dan Alikasi Sistem Pendukung Keputusan. Yogyakarta : Andi.

[6] Sanjaya. (2004). Pemograman Database 4. Yogyakarta : Andi.

[7] Saputra, E. (2008). Kopi. Yogyakarta : Harmoni.

[8] Triguno. (1997). Budaya Kerja Menciptakan Lingkungan Kondusif untuk Meningkatkan Produktivitas Kerja. Jakarta : Golden Terayon Press.

\section{BIOGRAFI PENULIS}

\begin{tabular}{|l|l|}
\hline & $\begin{array}{l}\text { Darjat Saripurna, S.Kom, M.Kom pria kelahiran Bogor 19 Juni } 1969 \text { merupakan Dosen } \\
\text { Tetap STMIK Triguna Dharma yang aktif mengampu mata kuliah pada bidang Sistem } \\
\text { Jaringan Komputer dan Pemrograman, beliau tamat S1 Universitas Gunadharma } \\
\text { bidang ilmu komputer dan tamat S2 Univesitas Putra Indonesia YPTK Padang }\end{array}$ \\
\end{tabular}

